\title{
RBF NEURAL NETWORKS FOR FUNCTION APPROXIMATION IN DYNAMIC MODELLING
}

\section{SIECI NEURONOWE RADIALNEJ FUNKCJI BAZOWEJ (RBF) DLA APROKSYMACJI FUNKCJI W MODELOWANIU DYNAMICZNYM}

\author{
Jakub NEDBALEK \\ VŠB - Technical University of Ostrava Authors' Affiliation Name of the Institution \\ in English \\ 17. Listopadu, 708 33, Ostrava, Czech republic \\ E-mail: jakubnedbalek@centrum.cz
}

\begin{abstract}
The paper demonstrates the comparison of Monte Carlo simulation algorithm with neural network enhancement in the reliability case study. With regard to process dynamics, we attempt to evaluate the tank system unreliability related to the initiative input parameters setting. The neural network is used in equation coefficients calculation, which is executed in each transient state. Due to the neural networks, for some of the initial component settings we can achieve the results of computation faster than in classical way of coefficients calculating and substituting into the equation.
\end{abstract}

Keywords: reliability, Monte Carlo, Radial Basis Function (RBF)

Streszczenie: W artykule przedstawiono porównanie algorytmu symulacyjnego wykorzystującego metodę Monte Carlo względem rozszerzenia sieci neuronowych na przypadek badania niezawodności obiektów. W odniesieniu do dynamiki procesu, podjęliśmy próbę oceny niepewności (zawodności) układu zbiornika w zależności od początkowych ustawień parametrów wejściowych. Do wyznaczenia współczynników równań wykorzystywane są sieci neuronowe, a proces obliczeniowy jest wykonywany dla każdego stanu przejściowego (nieustalonego). Dzięki zastosowaniu sieci neuronowych, dla pewnych ustawień wartości początkowych jesteśmy w stanie otrzymać wyniki obliczeń szybciej, niż w przypadku zastosowania klasycznej metody wyliczenia współczynników i podstawienia ich do równania wyjściowego.

Słowa kluczowe: niezawodność, metoda Monte Carlo, Radialna Funkcja Bazowa (RBF) 


\section{Introduction}

Let us have the model of a dynamic system, in which the temperature is evolving according to the time and initial component settings. The target is to specify the probability of a system failure, which is defined as exceeding the temperature bounds. We are also interested in the time necessary for computing the result. It is proposed to enhance the simulation algorithm with neural network tools which will be used in calculating the differential equation coefficients $a$ and $b$ (chap. 3 . relation (4)) being changed according to $\mathrm{k}_{\mathrm{i}}$ component states (on/off). After each $\mathrm{k}_{\mathrm{i}}$ switching, which is invoked by either passing the temperature transition state or failure of $\mathrm{k}_{\mathrm{i}}$ component, we must calculate new values of parameters $a$ and $b$ in equation (4) according to (2).

As a solution, it is appropriate to apply the RBF neural networks for the approximation of parameters (2) dependent on the $\mathrm{k}_{1}, \mathrm{k}_{2}$ and $\mathrm{k}_{3}$ component settings.

Optimal tool for constructing the simulation algorithm is the Monte Carlo (MC) method. This paper is derived from (Pasquet, et al., 1998; Nedbalek, 2007).

\section{The benchmark process description}

We dispose of the tank with warmed water, which temperature is kept in the specific maximal or minimal bounds - in this range, we consider system as stable and reliable. The system also contains two electric components, responsible for water heating, and security valve, which decreases the temperature. In the bottom of the tank, there is a faucet for water supplying. We suppose, the volume of water in the tank is constant during our experiment.

Let us define variables:

$\mathrm{T}(\mathrm{t})$ - temperature of water at the time $\mathrm{t}$;

Tempmax - maximal temperature of water in the tank;

Tempmax $=368,15 \mathrm{~K}$

Tempmin - minimal temperature of water, for $\mathrm{T}<\mathrm{Tempmin}$ failure occurs

Tempmin $=338,15 \mathrm{~K}$

Tempbas - security level for the minimal temperature

Tempbas $=343,13 \mathrm{~K}$

Temphau - security level for the maximal temperature

Temphau $=363,15 \mathrm{~K}$

$\mathrm{Secu}-$ reserve for the maximum temperature, for $\mathrm{T}>(\mathrm{Tempmax}+\mathrm{Secu})$ failure occurs, Secu $=2 \mathrm{~K}$

$\mathrm{M}$ - water weight, $\mathrm{M}=500 \mathrm{~kg}$

$\mathrm{Te}-$ external temperature, $\quad \mathrm{Te}=293 \mathrm{~K}$

A - tank surface, $\quad A=6 \mathrm{~m}^{2}$

$\mathrm{h}$ - thermal exchange coefficient, $\mathrm{h}=6 \mathrm{WK}^{-1} \mathrm{~m}^{-2}$

$\mathrm{c}_{\mathrm{p}}-$ measure heat capacity, $\mathrm{c}_{\mathrm{p}}=4184 \mathrm{Jkg}^{-1} \mathrm{~K}^{-1}$ 
RBF Neural networks for function approximation in dynamic modelling

$\mathrm{W}_{1}=\mathrm{W}_{2}$ - heating power, $\mathrm{W}=5000 \mathrm{~W}$

$\mathrm{tm}-$ process duration, $\mathrm{tm}=720 \mathrm{~h}$

hazard rate - transition to on-state

$\lambda_{\text {w1on }}=\lambda_{\text {w2on }}=6.10^{-4} \mathrm{~h}^{-1}$

hazard rate - transition to off-state

$\lambda_{\text {W1off }}=\lambda_{\text {W2off }}=4.10^{-4} \mathrm{~h}^{-1}$

hazard rate - transition to on or off-state

$\lambda_{\text {Vson }}=\lambda_{\text {Vsoff }}=1.10^{-3} \mathrm{~h}^{-1}$

\section{The equation solution}

To evaluate the probability failure, we need to write the differential equation, describing our system evolution. The equation obviously reflects the following points:

a/ decreasing the initial temperature due to heat penetration through the tank wall

$\mathrm{b} /$ increasing the water temperature caused by two heating components, if activated $\mathrm{c} /$ the water temperature decrease invoked by the security valve activation

Our equation comes from (Pasquet, et al., 1998) but it is altered for the behaviour of the system

$$
\frac{d T}{d t}=a T+b
$$

where

$$
\begin{aligned}
& a=-\left(\frac{A \cdot h}{M \cdot c_{p}}+\frac{Q_{s} \cdot c_{p} \cdot k_{3}}{M \cdot c_{p}}\right) \\
& b=\left[\frac{1}{M \cdot c_{p}} \cdot\left(A \cdot h \cdot T_{e}+Q_{s} \cdot c_{p} \cdot T_{e} \cdot k_{3}+W_{1} \cdot k_{1}+W_{2} \cdot k_{2}\right)\right]
\end{aligned}
$$

and

$$
Q_{s}=\frac{\frac{W_{1}+W_{2}}{\operatorname{Temp} \max -T_{e}}-A \cdot h}{c_{p}}
$$

The solution of (1) follows the equation

$$
T=\left(T_{0}+\frac{b}{a}\right) \exp ^{a \cdot t}-\frac{b}{a}
$$

where $T_{0}$ is the starting simulation temperature. 
The $k_{1}, k_{2}$ and $k_{3}$ coefficients equals 1 or 0 (the specific component is either on or off). For $\mathrm{k}_{1}=\mathrm{k}_{2}=1$ the heating components are active and temperature of water in the tank is increasing, for $\mathrm{k}_{3}=1$ the vent is unclosed and the temperature is decreasing, etc. We watch the process along the period of $t \mathrm{~m}=720 \mathrm{~h}$. The initial temperature is set between Tempmin and Tempmax, that is $-\mathrm{T}_{0}=353,15 \mathrm{~K}$.

\section{Creating an algorithm}

To construct the correct algorithm for our test case simulation, we take into account following points:

a) as mentioned before, for $\mathrm{T}<\mathrm{Tempmin}$ and also for $\mathrm{T}>(\mathrm{Tempmax}+\mathrm{Secu})$ failure occurs

b) the temperature passes by 5 stages generally - see the diagram:

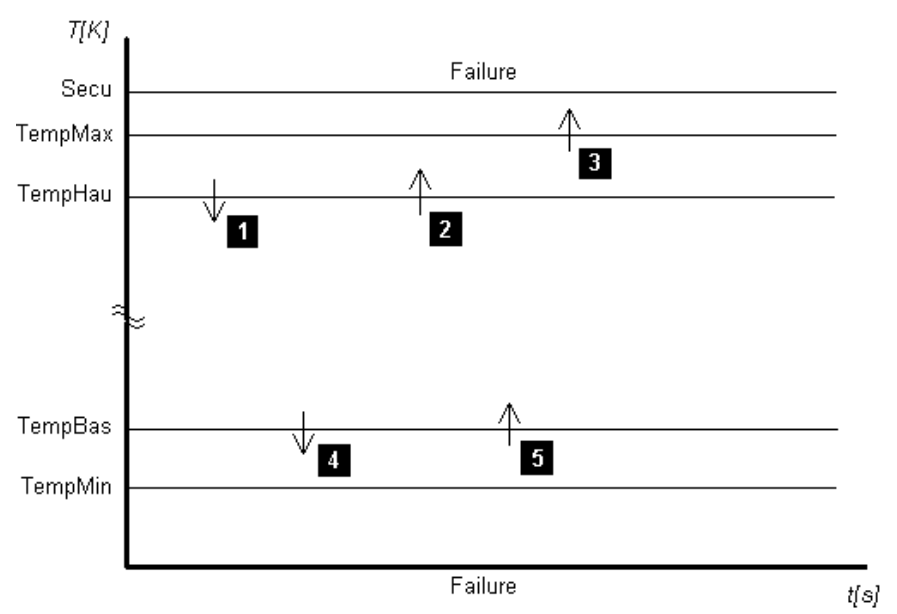

Figure 1. Dynamic rules of the system

For each of the temperature stages, the change (switch) of the specific component to the opposite state, that causes the required temperature turnover (see (1)) and stabilization in tolerable bounds. In case of random failure of the $\mathrm{k}_{\mathrm{i}}$ component, we keep on monitoring evolution of the temperature, until it exceeds limits - we consider the system as dysfunctional. (In the terms of the $\mathrm{k}_{\mathrm{i}}$ failure definition, the whole system does not have to be failed yet. The temperature of water in the tank could be still between bounds.)

c) There are following rules for components changes at temperature borders crossing:

State 1: If $\mathrm{T}(\mathrm{t}-1)>=\mathrm{Temphau}$ and $\mathrm{T}(\mathrm{t})<=$ Temphau, then $\mathrm{k}_{3}=0$ (vent will be closed)

State 2: If $\mathrm{T}(\mathrm{t}-1)<=$ Temphau and $\mathrm{T}(\mathrm{t})>=$ Temphau, then $\mathrm{k}_{1}=0$ (heating component num. 1 will be cut off) 
RBF Neural networks for function approximation in dynamic modelling

Sieci neuronowe radialnej funkcji bazowej (RBF) dla aproksymacji funkcji...

State 3: If $\mathrm{T}(\mathrm{t}-1)<=$ Tempmax and $\mathrm{T}(\mathrm{t})>=$ Tempmax, then $\mathrm{k}_{3}=1$ (vent will be opened)

State 4: If $\mathrm{T}(\mathrm{t}-1)>=$ Tempbas and $\mathrm{T}(\mathrm{t})<=$ Tempbas, then $\mathrm{k}_{1}=1 \& \mathrm{k}_{2}=1$ (both heating components are active)

State 5: If $\mathrm{T}(\mathrm{t}-1)<=$ Tempbas and $\mathrm{T}(\mathrm{t})>=$ Tempbas, then $\mathrm{k}_{2}=0$ (heating component num. 2 will be cut off)

d) time step option

Considering fact, that we present the evolution of (4) at time $t$ during the period of $\mathrm{tm}$, it is necessary to select an appropriate time to explore all detail changes of the temperature bahaviour and also to reduce the inadequate number of cycles of numerical simulation. The optimal solution seems to be the one minute pattern, which reflects suitably all changes at temperature borders crossing. Longer patterns do not suit our solution due to inaccuracies - a "jump-over" of some of the states mentioned in c) occurs sometimes.

e) Switching the component to the opposite state could happen at any time in the simulation due to random failure.

f) Period of the process is set for 720 hours.

\section{Application of the RBF}

Our simulation algorithm contains cycle, running over the process duration, in which (4) evolves according to time. This equation has coefficients $a$ and $b$, that depend on $\mathrm{k}_{\mathrm{i}}$ component states (on/off) - see (2). In the simulation, the $\mathrm{k}_{\mathrm{i}}$ state is influenced by either passing the temperature transition state (see Figure 1.) or failure of component itself. It means, that we must recalculate the $a$ and $b$ whenever the temperature transition or failure of the $k_{i}$ occurs. Simply, we are able to write lines of code to enumerate new values of the $a$ and $b$ right in the body of process duration cycle, whenever it is necessary to do so. The second possibility is to apply the Radial Basis Function (RBF) neural network to approximate the function of $a$ and $b$ coefficients depending on $\mathrm{k}_{\mathrm{i}}$ component states.

It is acceptable to use other types of neural network, nevertheless the RBF is obviously the best to solve the problem. This is the result of two main facts, firstly, we are not urged to design the network architecture (RBF has two layers standardly) and secondly, the RBF can not be trapped in a local minimum during training phase (Chan, et al., 1991). RBF complies our requirements on the function approximation (Yee and Haykin, 2001). Applying other types of neural network to unriddle this case study and to compare them with the used RBF network is the matter of a future research. 
At the beginning, we need to find out the convenient training set. This is obtained by simple computation of (2) for all combinations of the $k_{i}$ states (see Table 3.). Then, before the process duration cycle, we are ready to create and train the standard RBF architecture - there are several implementations and function support of the RBF in programming languages - for example, the Matlab software provides large neural network toolbox.

Consequently, the $a$ and $b$ parameters in (4) everywhere in the cycle are replaced with the callback function of the RBF network.

We can generally summarize, that the main modification consist in using the RBF as an auxiliary tool for working with equation (4) during the time of a simulation cycle. In any case, the $\mathrm{MC}$ construction of the algorithm remains the same for both cases.

\section{The results presentation}

Table 1. contains the distributional function of failure probability value averages for each initial components settings. The results were obtained for $10^{5}$ Monte Carlo simulations (1- the comp. active, 0 - comp. inactive at the beginning). The fifth column shows the computational time. All results are obtained in the state of $\mathrm{tm}=$ $720 \mathrm{~h}$. The simulation was implemented in the Matlab software.

Table 1. The results for $10^{5}$ cycles of Monte Carlo

\begin{tabular}{|c|c|c|c|c|}
\hline $\mathrm{k} 1$ & $\mathrm{k} 2$ & $\mathrm{k} 3$ & aver. $\mathrm{F}(\mathrm{tm})$ & aver. $\mathrm{t}[\mathrm{s}]$ \\
\hline \hline 0 & 0 & 0 & 0,3517 & 2315,0 \\
\hline 0 & 0 & 1 & 0,5303 & 2174,0 \\
\hline 0 & 1 & 0 & 0,5567 & 1928,6 \\
\hline 0 & 1 & 1 & 0,5312 & 2170,7 \\
\hline 1 & 0 & 0 & 0,3518 & 2332,1 \\
\hline 1 & 0 & 1 & 0,5306 & 2194,0 \\
\hline 1 & 1 & 0 & 0,5580 & 1920,4 \\
\hline 1 & 1 & 1 & 0,5602 & 1915,6 \\
\hline \hline aver. & & 0,4963 & 2118,8 \\
\hline sigma & & 0,0901 & 174,1 \\
\hline
\end{tabular}


RBF Neural networks for function approximation in dynamic modelling

Sieci neuronowe radialnej funkcji bazowej (RBF) dla aproksymacji funkcji...

Table 2. The results for the same Monte Carlo algorithm with RBF neural network enhancement

\begin{tabular}{|c|c|c|c|c|}
\hline $\mathrm{k} 1$ & $\mathrm{k} 2$ & $\mathrm{k} 3$ & aver.F(tm) & aver. $\mathrm{t}[\mathrm{s}]$ \\
\hline \hline 0 & 0 & 0 & 0,3510 & 2383,1 \\
\hline 0 & 0 & 1 & 0,5305 & 2037,1 \\
\hline 0 & 1 & 0 & 0,5574 & 2002,9 \\
\hline 0 & 1 & 1 & 0,5325 & 2042,2 \\
\hline 1 & 0 & 0 & 0,3506 & 2390,6 \\
\hline 1 & 0 & 1 & 0,5305 & 2040,5 \\
\hline 1 & 1 & 0 & 0,5578 & 1975,2 \\
\hline 1 & 1 & 1 & 0,5593 & 1968,9 \\
\hline \hline aver. & & 0,4962 & 2105,1 \\
\hline sigma & & 0,0906 & 176,2 \\
\hline
\end{tabular}

From comparison of Table 1. with Table 2., we can see the results of simulation at the time of 720 hours are very close - the RBF neural network is able to approximate with good accuracy (that was tested in the simulation code itself).

The results of computing time look more interesting - the average time necessary to simulate 720 hours long process is shorter by roughly $10 \mathrm{sec}$. This value seems to be neglectable, nevertheless the differences in results between the MC and the modification with RBF are larger when we look at the specific initial component settings.

Generally, we can express the presumption, that if the vent is opened and maximally one heating spiral is activated, it is more useful to enhance the MC algorithm with RBF network (the result is reached by 2- $2.5 \mathrm{~min}$ faster). In other cases, the Monte Carlo itself is faster ( $1 \mathrm{~min}$. advance).

In this place, we should stress out the information, that the comparison test on the $\mathrm{MC}$ and RBF network enhancement was executed on the computer, which had all applications, including hidden ones, and non-operation system processes not pertaining to simulation itself, halted. This measure is needed in order to provide the simulation the similar computing system capacity along the whole processing time and avert the distortion in result time values (operating system sometimes allocate to the other running applications the memory, as consequently leads to Matlab processing slow down).

With respect to the length of algorithm, the MC enhanced with the RBF is larger in creation and training of the network. In the simulation itself, the length of code remains the same.

In Table 2., we also considered time necessary to train the RBF network.

The results from Table 1 and 2 are presented in the Figures 2 and 3 The $\mathrm{x}$-axis denotes possible component states according to binary code, as it is shown in Table 3. 
Table3. The $\mathrm{k}_{\mathrm{i}}$ component states combination (1-on, 0-off)

\begin{tabular}{|c|c|c|c|}
\hline $\mathrm{X}-$ axis & $\mathrm{k} 1$ & $\mathrm{k} 2$ & $\mathrm{k} 3$ \\
\hline \hline 0 & 0 & 0 & 0 \\
\hline 1 & 0 & 0 & 1 \\
\hline 2 & 0 & 1 & 0 \\
\hline 3 & 0 & 1 & 1 \\
\hline 4 & 1 & 0 & 0 \\
\hline .. etc.
\end{tabular}

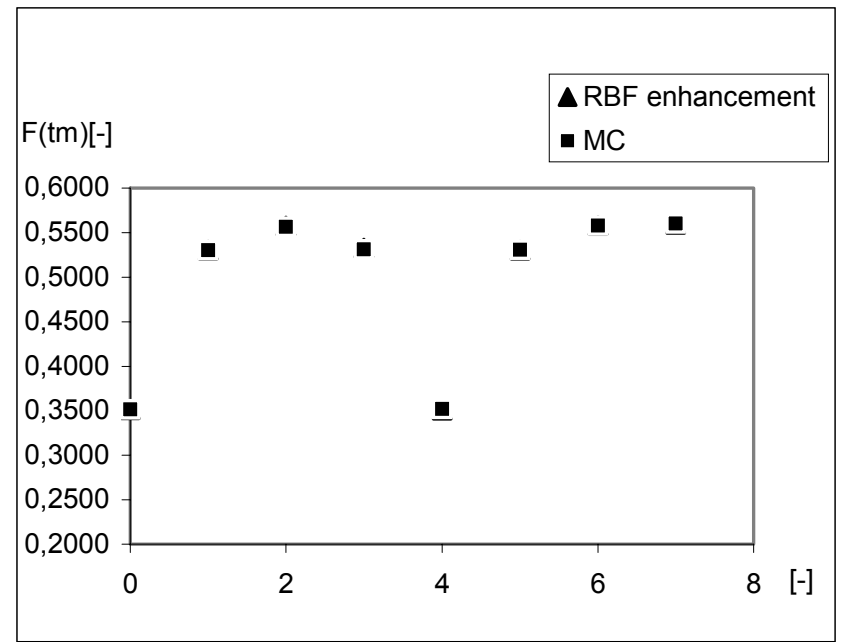

Figure 2. Failure probability comparison of the MC and the RBF neural network enhancement at time $t m$

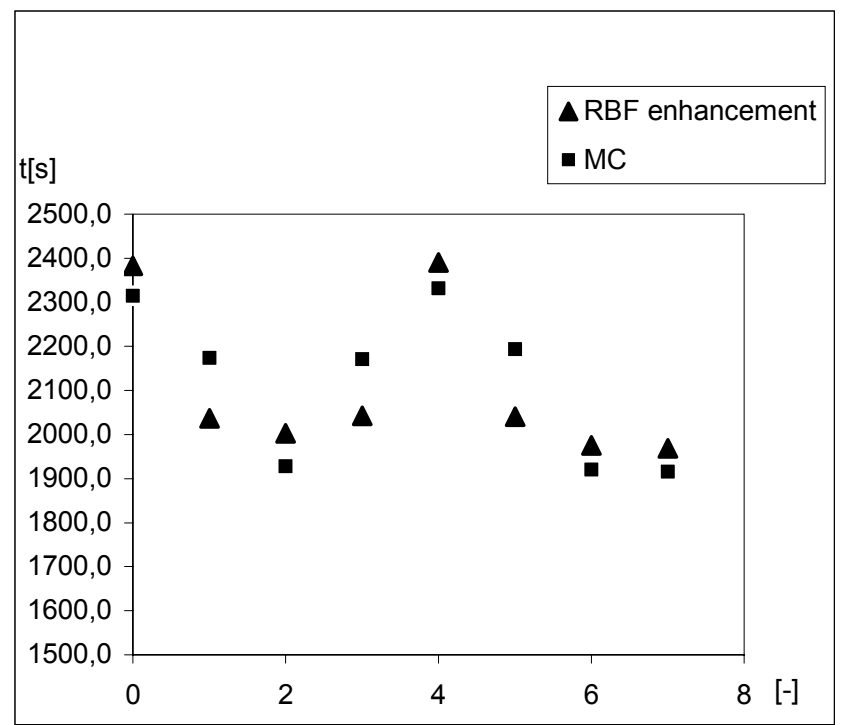

Figure 3. Computing time comparison of the $\mathrm{MC}$ and the RBF neural network enhancement 
RBF Neural networks for function approximation in dynamic modelling

Sieci neuronowe radialnej funkcji bazowej (RBF) dla aproksymacji funkcji...

\section{Conclusion}

For $10^{5}$ cycles, the failure probability at time $\mathrm{t}=720 \mathrm{hrs}$ equals to the value $\bar{F}_{(720)}=$ $0,4963 \pm 0,0901$ (MC) or 0,4962 $\pm 0,0906$ (RBF enhancement). The algorithm in chap. 4 is implemented in the Matlab software.

Out of the comparison of the Figure 1. and 2. follows, that the failure probability values are similar for both methods.

The whole computing time needed to obtain results for each initial component settings is shorter by approx. $10 \mathrm{sec}$. when we use enhancement with RBF network. The greater differences in time consumption are evident for specific settings - we can state, that if the security vent is opened and maximally one heating spiral is activated than it is preferable to add the RBF in algorithm (the result is known by 2-2.5 min faster), in all other cases, the plain Monte Carlo method is more suitable (faster by about $1 \mathrm{~min}$ ). Application of the RBF neural network can sometimes lead to obtain results faster. This information is likely to be applicable in other, not only dynamic simulation, test cases.

The author of this paper would like to thank for the financial support on behalf of the research and development project num. $1 M 06047$ (CQR), which is subsidized by the Ministry of Education of the $C R$. 


\section{References}

[1] Chen, S., Cowan, C.F.N. and Grant, P. M.: Orthogonal Least Squares Learning Algorithm for Radial Basis Function Networks. IEEE Transactions on Neural Networks, vol. 2, no. 2, March 1991, 302-309 s.

[2] Nedbálek, J.: The Temperature Stability of Liquid in the Tank. Risk, Quality and Reliability, Ostrava, 2007, 131-133 s. ISBN 978-80-248-1575-6.

[3] Pasquet S., Chatalet E., Padovani E., Zio E.: Use of Neural Networks to evaluate the RAMS' parameters of dynamic systems, Université de Technologie de Troyes France, Polytechnic of Milan Italy, 1998

[4] Pasquet S., Chatalet E.,Thomas, P. and Dutuit, Y.: Analysis of a Sequential, Non-Coherent and Looped System with Two Approaches: Petri Nets and Neural Networks. Proceeedings of International cenference on safety and reliability, ESREL'97, Lisabon, Portugal, 1997, 2257-2264 s.

[5] Virius, M.:Základy výpočetní techniky (Metoda Monte Carlo), ČVUT, Praha, 1985

[6] Yee, Paul V. and Haykin, S.: Regularized Radial Basis Function Networks: Theory and Applications, John Wiley, 2001.

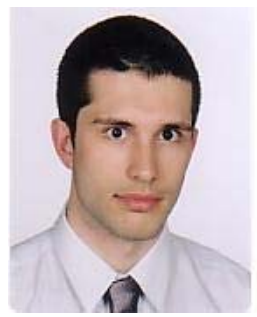

Born in 1981. Studied electrical engineering at VŠB - Technical University of Ostrava, graduated in 2004. He works for IT company and studies the doctorate degree on the institute of applied mathematics presently. He engages in object programming and neural networks. 